\title{
Akut gastroenterit vakalarında rotavirüs ve adenovirüs sıklığının araştırılması
}

\author{
Investigation of the frequency of rotavirus and adenovirus in acute gastroenteritis cases
}

Yeliz Tanrıverdi Çaycı, Gonca Yılmaz, Asuman Birinci

Ondokuz Mayıs Üniversitesi, Tıp Fakültesi, Tıbbi Mikrobiyoloji ABD, Samsun

\begin{abstract}
Özet
Amaç: Çalışmamızda hastanemize başvuran akut gastroenteritli hastalarda rotavirüs ve adenovirüs sıklığını, cinsiyet, yaş ve mevsimlere göre dağılımlarını retrospektif olarak belirlemeyi amaçladık.

Gereç ve yöntem: Mikrobiyoloji Laboratuvarına Ocak 2014-Haziran 2015 tarihleri arasında çeşitli poliklinik ve servislerden gönderilen, akut gastroenterit ön tanılı 2355 hastanın dışkı örneğinde rotavirüs ve adenovirüs antijenleri, renkli kromatografik yöntemle çalışan Rota-Adeno Card Test kiti kullanılarak araştırıldı.

Bulgular: Rotavirüs araştırılan 1101 örneğin, 129'unda (\%11,7) pozitiflik saptanmıştır. Adenovirüs ise 1254 örneğin 42 'sinde $(\% 3,3)$ pozitif saptanmıştır. İki örnekte, her iki virüs de saptanmıştır. Rotavirus ve adenovirus pozitiflik oranı en sık 13-24 ay grubunda saptanırken, rotavirüs ve adenovirüse bağlı enfeksiyonların kış ve ilkbahar aylarında daha sık görüldüğü saptanmıştır. Yaşa ve mevsimlere göre rotavirüs ve adeno virüs dağıımı incelendiğinde istatiksel olarak anlamlı bir ilişki saptanmamıştır ( $p>0,05)$.

Sonuç: Dışkı örneklerinde rotavirüs ve adenovirüs antijenlerinin araştırılması epidemiyolojik amaçlar ve gereksiz antibiyotik kullanımını önleme açısından önemlidir.
\end{abstract}

Pam Tıp Derg 2017;(1):61-65

Anahtar sözcükler: Rotavirüs, adenovirus, gastroenterit.

\begin{abstract}
Purpose: We aimed to evaluate the prevalance of rotavirus and adenovirus, and their distribution according to gender, age and season, retrospectively in patients with acute gastroenteritis.

Materials and methods: Samples from 2355 patients with suspected acute gastroenteritis, sent from different clinics and policlinics to Microbiology Laboratuary between January 2014 and June 2015 were investigated. Rotavirus and adenovirus antigens were investigated in stool samples using the kit Rota-Adeno Card Test which uses a colored chromatographic method.

Results:Rotavirus was detected in 129 of 1101 (11.7\%) specimens and adenovirus was detected in 42 of 1254 (3.3\%) specimens. Two specimens were positive for both of the viruses. Positivity for rotavirus and adenovirus was determined mostly in winter and spring and at $13-24$ months of age. There was no statistically significant difference between adenovirus and rotavirus antigen positivity regarding age and seasons $(p>0.05)$.

Conclusion: Investigation of rotavirus and adenovirus antigens in stool samples is important for epidemiological purposes and preventing the use of unnecessary antibiotics.
\end{abstract}

Pam Med J 2017;(1):61-65

Keywords: Rotavirus, adenovirus, gastroenteritis.

\section{Giriş}

İshal ile seyreden hastalıklar tüm dünyada yaygın olmakla birlikte, az gelişmiş ve gelişmekte olan ülkelerde özellikle küçük çocuklar için son derecede önemli bir sağlık sorunu ve önde gelen bir ölüm sebebidir. Çocukluk yaşlarında ortaya çıkan akut ishal ile seyreden hastalıkların en önemli sebebi gastrointestinal infeksiyonlardır [1]. İnfeksiyöz ishaller arasında viral gastroenteritler önemli bir yer tutmaktadır. Bu gastroenteritlerde rastlanan patojenler sıklıkla rotavirüs ve adenovirüslerdir [2-4].

Rotavirüsler bütün dünyada küçük çocuklarda ciddi diyarenin en yaygın sebeblerinden biridir [5]. Rotavirüs, akut gastroenterite bağlı hastaneye yatışların yaklaşık \% 40'ında tespit edilmiştir [6-8]. Özellikle 0-2 yaş arasında ve kış

Yeliz Tanrıverdi Çaycı

Yazışma Adresi: Ondokuz Mayıs Üniversitesi, Tıp Fakültesi, Tıbbi Mikrobiyoloji ABD, Samsun

e-mail: yeliztanriverdi@gmail.com 
aylarında sık görülebilmektedir [9]. Adenovirüs ise akut çocukluk çağı gastroenteritlerinin \% 5-15'inden sorumludur [10].

Adenovirüse bağlı enfeksiyonların yılın tüm aylarında görülebildiği belirtilmiştir [11]. Adenovirüs alttipleri arasında tip 40 ve 41 akut gastroenterit ile ilişkilidir. Enterik adenovirüsların enfeksiyon bulguları kaybolduktan sonra da viral atılımının uzun süre devam etmesi salgın yapabilmesini kolaylaştırdığı bilinmektedir [12].

Bu calışmada; viral gastroenterit etkenlerinin sürveyansı, hastalığın epidemiyolojisi ve izlenmesi açısından önemli olduğunu düşünülerek, hastanemize başvuran akut gastroenteritli hastalarda rotavirüs ve adenovirüs sıklığını, cinsiyet, yaş ve mevsimlere göre dağılımlarını incelemek amaçlanmıştır.

\section{Yöntemler}

Hastanemiz Mikrobiyoloji Laboratuvarına, Ocak 2014-Haziran 2015 tarihleri arasında çeşitli poliklinik ve servislerden gönderilen akut gastroenterit düşünülen 2355 hastanın verileri retrospektif olarak değerlendirmeye alınmıştır.

Çalışmamızda, taze dışkı örneklerinde rotavirüs ve adenovirüsün kalitatif tespitini yapan renkli kromatografik bir test olan RotaAdeno Card Test (CerTest, Biotec, İspanya) kitleri üretici firmanın önerileri doğrultusunda çalışılmıştır. Kullanılan ticari kit ile gastroenteritle ilgili yaygın serotiplerde (40-41 serotipleri dahil olmak üzere) bulunan adenovirüs hexon antijeni ile rotavirüs antijeni tespit edilmektedir. Bu testin özgüllüğü \%98, duyarlıı̆̆ >\%99 olarak belirtilmiştir (13). Rotavirüs ve adenovirüs gastroenteritlerinin sıklığının mevsimlere, yaşa ve cinsiyete göre dağılımı değerlendirilmiştir.

Rotavirüs ve adenovirüs sıklığının mevsimlere ve yaşa göre dağılımı ki-kare testi kullanılarak değerlendirilmiştir, $p<0,05$ istatiksel olarak anlamlı kabul edilmiştir.

\section{Bulgular}

Ön tanı olarak akut gastroenterit düşünülen toplam 2355 dışkı örneği değerlendirmeye alınmıştır. Hastaların yaşları 0-84 yaş arasında değiştiği görülmüştür. Rotavirüs araştırılan 1101 örneğin, 129'unda (\%11,7) pozitiflik saptanmıştır. Adenovirüs açısından ise 1254 örneğin 42'sinde $(\% 3,3)$ pozitiflik saptanmıştır. İki örnekte, her iki virüs için birlikte pozitiflik saptanmıştır. Rotavirüs antijeni saptanan olguların, 59'unun (\%12) cinsiyeti kadın, 70'inin (\%11,5) cinsiyeti erkek, adenovirüs antijeni saptanan olguların 17'sinin (\%3) cinsiyeti kadın, 25'inin $(\% 3,7)$ cinsiyeti erkek olarak saptanmıştır. Rotavirüs olgularının 69'unun $(\% 13,4)$ 0-12 ay aralığında, 25'inin (\%24,5) 13-24 ay ve 20 'sinin $(\% 11,7)$ 3-5 yaş aralığında ve 42 adenovirüs olgusunun 18 'inin (\%3,1) 0-12 ay aralığında,10'unun (\%8,2) 13-24 ay ve 4'ünün $(\% 2,1) 3-5$ yaş aralığında olduğu gözlemlenmiştir (Tablo 1,Tablo 2). Yaşa göre rotavirüs ve adeno virüs dağılımında istatiksel olarak anlamlı bir ilişki saptanmamıştır $(p>0,05)$.

Mevsime göre rotavirüs ve adenovirüs enfeksiyonlarının dağılımı incelendiğinde rotavirüsün en sık ilkbahar $56(\% 18,6)$ ve kış 64 (\%17) aylarında; adenovirüsün de kış 20 $(\% 4,6)$ ve ilkbahar $14(\% 3,4)$ aylarında daha sık enfeksiyona neden olduğu belirlenmiştir (Tablo1 ve Tablo 2). Ancak rotavirüs ve adenovirüs antijeni saptanan olguların mevsimsel dağılımında anlamlı bir ilişki saptanmamıştır $(p>0,05)$.

\section{Tartışma}

Gelişmiş ve gelişmekte olan ülkelerde çocukluk çağı ishallerinin büyük kısmından virüsler sorumludur. Etiyolojik ajanlar göz önüne alındığında viral patojenlerin \%30-40'lara varan oranlarla ilk sırayı aldıkları bilinmektedir [14]. Rotavirüs ve enterik adenovirüsler çocukluk çağı viral gastroenteritlerin en önemli etkenleridir [15,16]. Dünyada ve ülkemizde yapılan çeşitli çalışmalarda rotavirüsün, viral gastroenterit vakalarının \% 11-71'inden sorumlu olduğu bildirilirken, bu oran adenovirüs için \% 2-22,2 olarak belirtilmiştir [11,17,18]. Bizim çalışmamızda örneklerin \% 11,7 'sinde rotavirüs, \% 3,3'ünde adenovirüs antijeni saptanmıştır

Cinsiyet açısından genel olarak viral gastroenterit sıklığında ülkemizde yapılan çeşitli çalışmalarda bir fark olmadığı bildirilmiştir $[11,16,19]$. Bizim çalışmamızda da, rotavirüs ve adenovirüs pozitifliği açısından cinsiyetler arasında benzer oranlar saptanmıştır.

Yaş gruplarına göre viral antijen pozitiflik oranlarının dağılımı incelendiğinde; çalışmamızda en yüksek pozitiflik oranı rotavirüs ve adenovirüs için sırasıyla $\% 24,5$ ve $\% 8,2$ oranlarında olmak üzere $13-24$ ay arasında saptanmıştır. Kocaeli'de [20] yapılan bir çalışmada rotavirüs olgularının \%40,2'sinin 
Tablo 1. Rotavirüs antijeni pozitiflik oranının cinsiyet, yaş grupları ve mevsimlere göre dağılımı.

\begin{tabular}{lcccc}
\hline & \multicolumn{2}{c}{ Olgu } & \multicolumn{2}{c}{ Pozitif } \\
\hline & Sayı & $\%$ & 59 & $\%$ \\
Cinsiyet & & & Sayı & 12 \\
Kız & 490 & 44,5 & 70 & 11,5 \\
Erkek & 611 & 55,5 & & \\
Yaş Grupları & & & 69 & 13,4 \\
0-12 ay & 513 & 46,6 & 25 & 24,5 \\
13-24 ay & 102 & 9,3 & 10 & 11,7 \\
3-5 yaş & 171 & 15,5 & 11 & 7,8 \\
6-14 yaş & 141 & 12,8 & 4 & 2,3 \\
$>14$ yaş & 174 & 15,8 & & 18,6 \\
Mevsimler & & & 56 & 2,7 \\
Illkbahar & 301 & 27,3 & 6 & 1,4 \\
Yaz & 222 & 20,2 & 3 & 17 \\
Sonbahar & 202 & 18,3 & 64 & 11,7 \\
Kış & 376 & 34,2 & 129 & \\
Toplam & 1101 & 100 & & \\
\hline
\end{tabular}

Tablo 2. Adenovirüs antijeni pozitiflik oranının cinsiyet, yaş grupları ve mevsimlere göre dağılımı.

\begin{tabular}{|c|c|c|c|c|}
\hline & \multicolumn{2}{|c|}{ Olgu } & \multicolumn{2}{|c|}{ Pozitif } \\
\hline & Sayı & $\%$ & Sayı & $\%$ \\
\hline \multicolumn{5}{|l|}{ Cinsiyet } \\
\hline $\mathrm{K} ı \mathrm{Z}$ & 576 & 46 & 17 & 3 \\
\hline Erkek & 678 & 54 & 25 & 3,7 \\
\hline \multicolumn{5}{|l|}{ Yaş Grupları } \\
\hline $0-12$ ay & 571 & 45,6 & 18 & 3,1 \\
\hline $13-24$ ay & 121 & 9,6 & 10 & 8,2 \\
\hline $3-5$ yaş & 188 & 15 & 4 & 2,1 \\
\hline $6-14$ yaş & 253 & 20,2 & 10 & 3,9 \\
\hline$>14$ yaş & 121 & 9,6 & 0 & 0 \\
\hline \multicolumn{5}{|l|}{ Mevsimler } \\
\hline İlkbahar & 406 & 32,4 & 14 & 3,4 \\
\hline Yaz & 216 & 17,2 & 5 & 2,3 \\
\hline Sonbahar & 197 & 15,7 & 3 & 1,5 \\
\hline Kış & 435 & 34,7 & 20 & 4,6 \\
\hline Toplam & 1254 & 100 & 42 & 3,3 \\
\hline
\end{tabular}

ve adenovirüs olgularının \%38,7'sinin 0-1 yaş arasında olduğu bildirilmiştir. Yine Gültepe ve ark.'nın [21] yaptığı bir çalışmada rotavirüs pozitifliği en sık 0-1 yaş (\%42) ve 1-2 yaş (\%27) gruplarında görülürken, benzer şekide adenovirüs pozitifliği de en sık 0-1 yaş (\%47) ile 1-2 yaş (\%23) gruplarında görülmüştür. Başka bir çalışmada, 302 çocuk hastanın dışkı örneği rotavirüs açısından immünokromatografik yöntemle incelenmiş ve pozitifliğin en sık 0-24 ay yaş grubunda ve kış mevsiminde görüldüğü tespit edilmiştir [22]. Çalgın ve ark.'da çalışmalarında rotavirus pozitifliğini 13 ay- 4 yaş arasında en yüksek olarak saptamışlardır [23]. 
Ülkemizde rotavirüs gastroenterit vakaları sıklıkla kış aylarında ve ilkbahar başında görülürken, adenovirüs gatroenteritleri ise tüm yıl boyunca görülebilmektedir $\quad[11,17,24,25]$. Çalışmamızda rotavirüs ve adenovirüs enfeksiyonları daha çok aralık, ocak, şubat aylarında görülmekle beraber istatiksel olarak anlamlı farklılık saptanmamıştır. Iraz ve Ceylan, rotavirüs pozitifliğini en yüksek kış ve ilkbahar mevsimlerinde tespit etmişlerdir [26]. Benzer bir çalışmada rotavirüs enfeksiyonlarının kış aylarında daha sık (\%46.3), adenovirüs enfeksiyonlarının ise yıl boyunca hemen hemen aynı sıklıkta görüldüğü belirtilmiştir [22]. Altındiş ve ark. ise çalışmalarında adenovirusun enfeksiyon sıklığının en yüksek Aralık ayında (\%40) olduğunda belirtmişlerdir [25].

Çalışmamızda hastaların demografik verilerini (altta yatan hastalık, meslek vb.) inceleyememiş olmamız çalışmamızın kısıtılıkları arasında yer almaktadır.

Sonuç olarak rotavirüs ve adenovirüs gastroenteritlerinin özellikle çocukluk çağında yaygın olarak görüldüğü ve bu yaş grubundaki gastroenterit vakalarında bakteriyel ve paraziter etkenlerin yanında araştırılmasının hem erken tanıya katkı sağlayacağı hem de gereksiz antibiyotik kullanımını azaltacağı düşüncesindeyiz.

Çıkar İlişkisi: Yazarlar çıkar ilişkisi olmadığını beyan eder.

\section{Kaynaklar}

1. Assis AM. Growth faltering in childhood related to diarrheae: A longitudinal community based study. Eur J Clin Nutr 2005;59:1317-1323.

2. Farkas T, Jiang XI. Rotaviruses, Caliciviruses, Astroviruses, Enteric adenoviruses and other diarrheic viruses. In: Murray PR, Baron EJ, Jorgensen JH, Landry ML, Pfaller MAed. Manual of clinical microbiology. 9th ed. Washington DC: ASM Press, 2007;1453-1469.

3. Ferreira CEO, Raboni SM, Pereira LA. Viral acute gastroenteritis: clinical and epidemiological features of co-infected patients. Braz J Infect Dis 2012;16: 267-272.

4. Ferreira MSR, Xavier MdPTP, Tinga ACDC, et al. Assessment of Gastroenteric Viruses Frequency in a Children's Day Care Center in Rio De Janeiro, Brazil: A Fifteen Year Study (1994-2008). PLoS ONE, 2012;7:e33754.
5. Başustaoğlu, AC, Yıldıran ŞT, Tanyüksel M, Yapar M (çev. Ed.) Tıbbi mikrobiyoloji. 6. ed. Ankara: Atlas Kitapçılık, 2014;601-608.

6. Ehlken B, Laubereau B, Karmaus W, Petersen $\mathrm{G}$, Rohwedder $\mathrm{A}$, Forster $\mathrm{J}$ and the RoMoD Study Group. Prospective population-based study on rotavirüs disease in Germany. Acta Paediatrica 2002;91:769-775.

7. Lynch M, O'Halloran F, Whyte D, Fanning S, Cryan B, Glass R. Rotavirus in Ireland: national estimates of disease burden, 1997 to 1998. Pediatric Infectious Disease Journal 2001;20:693-698.

8. Roman E, Wilhelmi I, Colomina J et al. Acute viral gastroenteritis: proportion and clinical relevance of multiple infections in Spanish children Journal of Medical Microbiology 2003;52:435-440.

9. Pickering LK. Summaries of infectious Diseases, Adenovirüs infections. In: Pickering LK Ed. American Academy of Pediatrics Red Book, New York: Elk Grove Co, 2003;90-192.

10. Clark B, McKendrick M. A review of viral gastroenteritis. Curr Opin Infect Dis 2004;17:461469.

11. Tekin A. Mardin'deki akut gastroenteritli çocuklarda Rotavirüs ve Enterik Adenovirüs sıklığı. Klin Den Ar Derg 2010;1:41-45.

12. Rodriguez-Baez N, O'Brien R, Qiu SQ, Bass DM. Astrovirus, adenovirüs, and rotavirüs in hospitalized children: prevalence and association with gastroenteritis. Pediatri Gastroenterol Nutr 2002;35:64-68.

13. Certest Biotec. http://www.certest.es/products/ rotavirus-adenovirus-3. Erişim tarihi 12 Mart 2016.

14. Bulut $Y$, İşeri $L$, Ağel $E$, Durmaz $B$ : Akut gastroenterit ön tanılı çocuklarda rotavirüs pozitifliği. İnönü Üniv Tıp Bült 2003;10:143-145.

15. Saderi H, Roustai MH, Sabahi F, Sadeghizadeh M, Owlia P, De Jong JC. Incidence of enteric adenovirüs gastroenteritis in Iranian children. J Clin Virol 2002;24:1-5.

16. Şimşek Y, Bostancı I, Bozdayı G, Öner N, Kamruddin A, Rota S. Frequency and serotype features of rotavirüs in $0-5$ age children with acute gastroenteritis. Turkiye Klinikleri J Pediatr 2007;16:165-170.

17. Gül M, Garipardıç M, Çıragil P, Aral M, Karabiber H, Güler İ. 0-5 yaş arası gastroenteritli çocuklarda rotavirüs ve adenovirüs tip 40/41 araştırılması. Ankem Derg 2005;19:64-67.

18. Yousefi Rad A, Gözalan A. Detection of Rotavirus and Enteric Adenovirus Antigens in Outpatients with Gastroenteritis. Turkiye Klinikleri J Med Sci 2010;30:174-179.

19. Türk Dağı H, Fındık D. Akut gastroenteritli hastalarda rotavirüs ve adenovirüs antijenlerinin araştırılması. J Clin Exp Invest 2014;5:256-260. 
20. Yazıcı V, ManzurY, AkbulutA. Akut gastroenteritte rotavirüs ve enterik adenovirüs infeksiyonları. Klimik Dergisi 2013;26:13-16.

21. Gültepe B, Güdücüoğlu H, Çıkman A, Parlak $M$, Berktaş M. Gastroenteritlerinde rotavirüs ve adenovirüs sıklığı. Türk Mikrobiyol Cem Derg 2012;42:116-120.

22. Inci $A$, Urhan $B$. The frequency of Rotavirus in children with acute gastroenteritis. J Clin Anal Med 2015;6:449-451.

23. Çalgın MK, Çetinkol $Y$, Altunçekiç Yıldırım A, Erdil A, Dağlı A. Ordu ilindeki akut gastroenteritli çocuklarda rotavirüs ve enterik adenovirüs sıklığının araştırılması. Ankem Derg 2015;29:5965.

24. Biçer S, Şahin GT, Koncay B. Çocuk acil servisinde saptanan rotavirüs gastroenteriti olgularının sıklığı. J Pediatr Inf 2008;3:96-99.

25. Altındiş M, Beştepe G, Çeri A, Yavru S, Kalaycı R. Akut ishal yakınmalı çocuklarda rotavirüs ve enterik adenovirüs sıklığı. S.D.Ü. Tıp Fak. Derg 2008;15:17-20.

26. Iraz M, Ceylan A. Akut gastroenteritli 0-5 yaş arası çocuklarda rotavirüs sıklığı, ANKEM Derg 2013;27:2-6. 